\title{
Partial altitudinal migration of the Near Threatened satyr tragopan Tragopan satyra in the Bhutan Himalayas: implications for conservation in mountainous environments
}

\author{
Nawang Norbu, Ugyen, Martin C. Wikelski and David S. Wilcove
}

\begin{abstract}
Relative to long-distance migrants, altitudinal migrants have been understudied, perhaps because of a perception that their migrations are less complex and therefore easier to protect. Nonetheless, altitudinal migrants may be at risk as they are subject to ongoing anthropogenic pressure from land use and climate change. We used global positioning system/accelerometer telemetry to track the partial altitudinal migration of the satyr tragopan Tragopan satyra in central Bhutan. The birds displayed a surprising diversity of migratory strategies: some individuals did not migrate, others crossed multiple mountains to their winter ranges, others descended particular mountains, and others ascended higher up into the mountains in winter. In all cases migration between summer breeding and winter non-breeding grounds was accomplished largely by walking, not by flying. Females migrated in a south-easterly direction whereas males migrated in random directions. During winter, migrants occupied south-east facing slopes whereas residents remained on south-west facing slopes. Migratory and resident tragopans utilized a range of forest types, with migratory individuals preferring cool broadleaved forests during winter. These complex patterns of migration suggest that conservation measures should extend across multiple mountains, protect the full range of forest types and encompass multiple landscape configurations to protect aspect diversity. Given the diversity of migratory strategies employed by this single species it seems clear that more research on altitudinal migrants is needed to understand what must be done to ensure their future in an era of widespread land-use and climate change.
\end{abstract}

Keywords Altitudinal migration, Bhutan, conservation, mountains, partial migration, protected areas, satyr tragopan, Thrumshingla National Park

\footnotetext{
NAWANG Norbu* (Corresponding author) and UGyen Ugyen Wangchuck Institute for Conservation and Environment, Lamai Gompa Dzong, Bumtang, Bhutan. E-mail norbu.nawang@gmail.com

MaRTin C. WiKelski Max Planck Institute for Ornithology, Radolfzell, Germany

DAvid S. WILcove Woodrow Wilson School for Public and International Affairs and Department of Ecology and Evolutionary Biology, Princeton University, USA

*Also at: The International Max Planck Research School for Organismal Biology, University of Konstanz, Germany

Received 20 January 2015. Revision requested 26 February 2015

Accepted 8 June 2015. First published online 28 March 2016.
}

To view supplementary material for this article, please visit http://dx.doi.org/10.1017/So030605315000757

\section{Introduction}

R elative to long-distance migrants, altitudinal migrants Chave been understudied, perhaps because of a perception that their migrations are less complex and easier to protect. In montane regions many species migrate altitudinally up and down mountain slopes (Stiles, 1988; Powell \& Bjork, 1995; Burgess \& Mlingwa, 2000; Chaves-Champos et al., 2003; Faaborg et al., 2010). Although attempts have been made (Laymon, 1989; Cade \& Hoffman, 1993; Powell \& Bjork, 1994; Chaves-Champos et al., 2003; Hess et al., 2012), few studies have illustrated patterns of altitudinal migration using telemetry (but see Norbu et al., 2013).

Montane regions, which cover an estimated $24.3 \%$ of land surface area (Kapos et al., 2000), are being exposed to climate change (Nogués-Bravo et al., 2007) and loss of forest cover (Blyth et al., 2002; Pandit et al., 2007), both of which will put mountain species and their migrations at risk (Inouye et al., 2000).

In general, animal migrations are undergoing decline (Wilcove \& Wikelski, 2008; Harris et al., 2009) as a result of habitat loss and climate change (Both et al., 2006; Møller et al., 2008). These declines are of concern because migration is important in maintaining ecological processes and shaping ecosystems (Holland et al., 2006; Wilcove \& Wikelski, 2008; Bowlin et al., 2010). However, the conservation of migratory species remains a daunting task, given the complexity of the phenomenon and the geographical scale at which it occurs (Moore et al., 1995; Wilcove, 2008; Faaborg et al., 2010).

In comparison to long-distance migrants, the conservation of altitudinal migrants may be perceived to be relatively easier given their occurrence over a smaller geographical area. This may not necessarily be the case, however. For example, telemetry studies (Powell \& Bjork, 1994, 1995, 2004) have shown that habitat types required by two altitudinally migrating species, the resplendent quetzal Pharomachrus mocinno and three-wattled bellbird Procnias tricarunculata, were not included within Costa Rica's protected area system. To ensure the protection of altitudinal migrants, the 


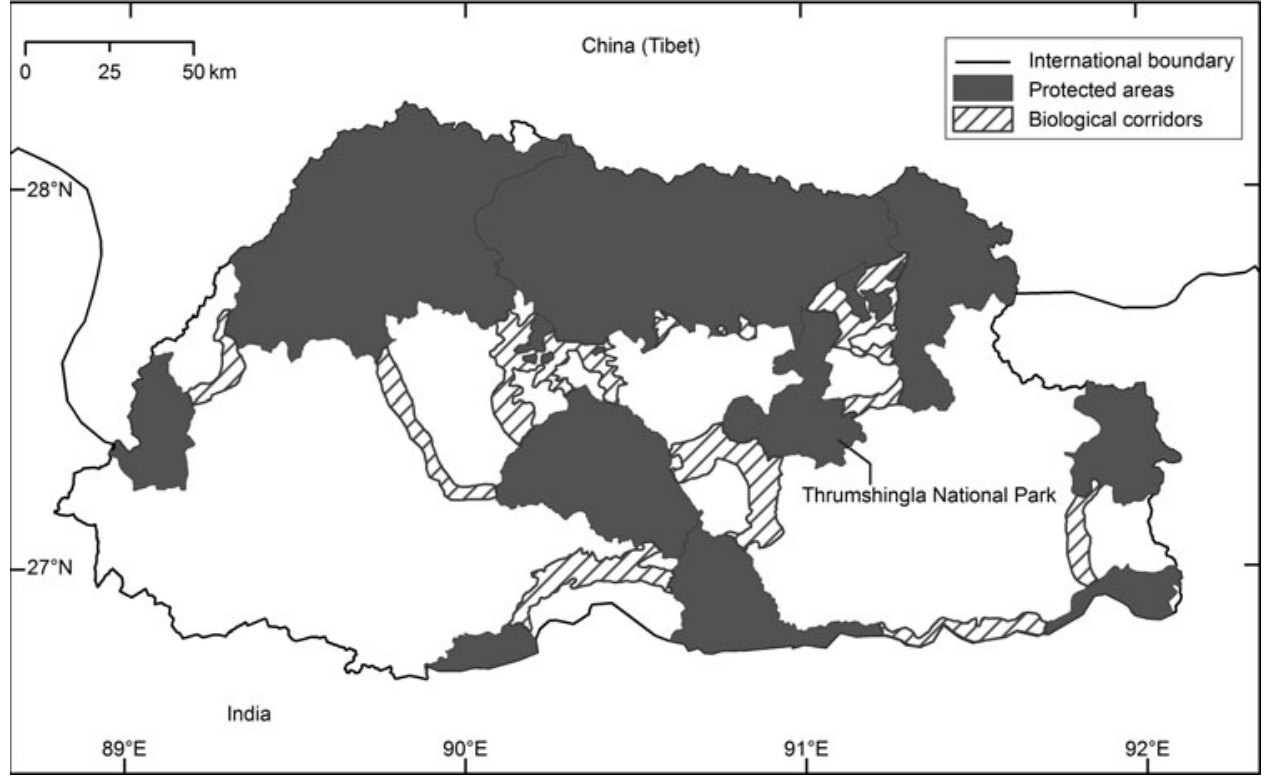

FIG. 1 Location of the study area in Thrumshingla National Park, Bhutan. incorporation of all habitat types within reserve systems has been recommended as a principle of effective reserve design (Powell \& Bjork, 1994, 1995, 2004).

Establishment of protected areas (Terborgh et al., 2002; Brooks et al., 2004; Cantú-Salazar et al., 2013) and biological corridors (Roever et al., 2013) has become one of the key strategies to protect biodiversity. However, the adequacy and effectiveness of protected areas and corridors have been questioned (Hobbs, 1992; Beier \& Noss, 1998; Ervin, 2003), particularly regarding the conservation of migratory species (Moore et al., 1995; Thirgood et al., 2004; Martin et al., 2007); for example, wildlife movement data have been used in only a few instances to influence corridor design (Zeller et al., 2012).

With 111 protected areas, the network of protected areas in the Himalayas covers an estimated $741,706 \mathrm{~km}^{2}$ (Chettri et al., 2008). Despite this extensive coverage we are not aware of any telemetry-based study of altitudinal migrants to assess the effectiveness of protected areas in the Himalayas. Given that the Himalayas are undergoing habitat loss (Pandit et al., 2007) and climate change (Shrestha et al., 2012), and noting that many of the birds in the Himalayas are altitudinal migrants (Inskipp et al., 1999; Grimmet et al., 2000; BirdLife International, 2015), data are needed to test the adequacy of conservation landscapes in protecting altitudinally migrating species.

We used global positioning system (GPS)/accelerometer telemetry to track the seasonal migration of the satyr tragopan Tragopan satyra, a pheasant endemic to the central and eastern Himalayas of Bhutan, India and Nepal. The species (hereafter referred to as the tragopan) is categorized as Near Threatened on the IUCN Red List (BirdLife International, 2012a) and listed on Appendix III of CITES (2015). Only an estimated 20,000 individuals (c. 6,000-15,000 mature adults) are believed to be extant in the wild (BirdLife International, $2012 b$ ). The tragopan has been shown to be a partial altitudinal migrant (Norbu et al., 2013). Here, we assess the adequacy of a protected area in Bhutan to provide protection for an altitudinal migrant, by examining the migration mode, patterns and habitat requirements of the tragopan.

\section{Study area}

We studied the tragopan in Thrumshingla National Park, a $905 \mathrm{~km}^{2}$ protected area in central Bhutan (Fig. 1), at 1,500$4,500 \mathrm{~m}$ elevation. Mean daily temperature is $-8-25^{\circ} \mathrm{C}$. The area has four distinct seasons, with most rainfall occurring during May-August as part of the Asian monsoons. The study area is mostly covered by conifer forests dominated by Bhutan fir Abies densa, with rhododendron understorey at higher elevations $(>3,000 \mathrm{~m})$ transitioning to mixed conifer forests $(2,400-3,000 \mathrm{~m})$ comprising Sikkim spruce Picea spinulosa, Himalayan hemlock Tsuga dumosa and Sikkim larch Larix griffithii. Below 2,400 m conifer forests give way to conifer-broadleaved mixed forests and to cool broadleaved forests of oak Quercus glauca and Quercus lamellosa. There are also a few patches of open grazing areas that are used by nomadic cattle herders.

\section{Methods}

Trapping We trapped tragopans during June-October in 2009, 2010 and 2011 using neck noose traps laid along ridges known to be used by tragopans, which we barricaded with bamboo and shrubs. We flushed tragopans towards traps during early mornings and evenings. In 2009, when the birds were trapped for the first time, all captured individuals were released immediately after GPS tags were attached, to 
reduce the risk of any handling-related fatalities. Tragopans captured in 2010 and 2011 were weighed (to the nearest $\mathrm{g}$ ) and their tarsus length $(\mathrm{mm})$ and beak size $(\mathrm{mm})$ were measured. All trapping was approved by the Ministry of Agriculture and Forests in Bhutan.

GPS/accelerometer tags and data acquisition We used GPS/accelerometer tags (e-obs, Munich, Germany) to record the location and activity of tagged tragopans. The recorded data (i.e. location, elevation, date, time and acceleration) were downloaded remotely with a hand-held base station after each individual was relocated via its tag's VHF radio pulse. To help locate tagged birds the tags were programmed to ping every 2 seconds for 2 hours every day. Tags with harnesses weighed $45 \mathrm{~g}$. Except for the smallest individual, which weighed $910 \mathrm{~g}$, all tagged tragopans weighed $>_{1} \mathrm{~kg}$, with the largest weighing $1.8 \mathrm{~kg}$; the mean weight of 28 individuals was $1.46 \mathrm{~kg}$. At the mean weight, tags constituted $3 \%$ of the body weight; this is within the acceptable limit of $5 \%$ (Hawkins, 2004). Tags deployed in 2009 were programmed to record a GPS reading every 2 hours during 04.00-22.00. Given battery power constraints, in 2010 tags were programmed to record only two GPS readings per day, at 06.00 and 14.00 , and in 2011 they recorded three readings per day, at $08.00,14.00$ and 20.00 . To optimize battery performance, tags were programmed with a give-up time of 2 minutes, after which the tag would cease trying to obtain a GPS reading for a particular location.

Distance, duration and direction of migration We categorized all individuals that showed distinct non-overlapping summer and winter ranges (i.e. individuals that stayed $>3$ months at winter ranges) as migrants and the remainder as residents. Using the Show Elevation Profile tool in Google Earth v. 5.2 (Google Inc., Mountain View, USA) we measured migration distance as the distance between the location on the day when migration was initiated and the first location on the day when migration was terminated. We ascertained the direction of migration between summer and winter habitat using the Ruler tool in Google Earth.

Habitat use patterns For all individuals we overlaid GPS fixes on a land-cover map produced by the Ministry of Agriculture and Forests (2011). We counted total fixes for all individuals in various land-cover types across months. To test whether habitat preferences changed over seasons, we fitted generalized linear models in $R$ v. 3.o.2 ( $\mathrm{R}$ Development Core Team, 2014) to predict the proportion of habitats used (as indicated by the total GPS fixes within a habitat in each month) across months during SeptemberApril. For every GPS point recorded during the winter period (December-February) we extracted the aspect (in degrees) of the given location from a digital elevation model at a spatial resolution of $30 \times 30 \mathrm{~m}^{2}$. For each individual, using the Rayleigh statistic at a significance level of 0.05 , we assessed whether the aspect data were distributed uniformly or whether the individual showed a preference for a particular aspect. For individuals with a significant preference for a certain aspect, we calculated the mean aspect for each individual and calculated summary statistics separately for two groups: migrants and residents. We used Oriana v. 4.02 (Kovach Computing Services, Anglesey, UK) for all circular statistics.

\section{Quantifying bouts of flying/running, walking and resting}

We used accelerometer data (Wilson et al., 2007; Brown et al., 2013) to quantify bouts of flying/running, walking and resting. Acceleration data were obtained for the vertical $\mathrm{Z}$-axis (up-and-down axis) continuously for 24 hours every day from tag initiation to the last date of tag download. Acceleration data consisted of 36 raw acceleration values within every 2-minute interval (bout). We calculated differences between successive raw observations and obtained the variances of these differences for each 2-minute bout. We then used the variances to categorize each 2-minute bout into one of three categories of activity: flight/running, walking/ foraging or resting. We categorized all variances $<125$ as resting, $125-1,500$ as walking/foraging, and $>1,500$ as flying/running. We could not separate flying and running because the activity signatures for the two were difficult to distinguish. We checked the accuracy of our categorization by cross checking with categorizations obtained using Acceleration Viewer (Movebank, Max Planck Institute of Ornithology, Munich, Germany). To calibrate activity signatures for the software we observed a tagged domestic chicken Gallus gallus for 2 days and recorded the times when it walked, ran, flew and rested. We then inspected its activity patterns in Acceleration Viewer.

Data analysis and archiving All geographical information system operations were carried out with $\operatorname{ArcGIS} v$ v. 9.3.1 (ESRI, Redlands, USA) and statistical tests with $R$ v. 3.0.2 (R Development Core Team, 2014). All data have been archived at Movebank (2015).

\section{Results}

We obtained movement data for 24 individuals over 3 years (2009-2011). Fourteen (nine females and five males) migrated and 10 (two females and eight males) did not. Of the 14 migrants, we obtained return migration data for only 4 females and 1 male (Table 1 ). 
TABLE 1 Numbers of satyr tragopans Tragopan satyra for which movement data were recorded during autumn and spring migrations in Thrumshingla National Park, Bhutan (Fig. 1), during 2009 -2012, including sedentary individuals.

\begin{tabular}{lllll}
\hline \multicolumn{3}{c}{\begin{tabular}{l} 
No. of individuals for which data were recorded \\
\cline { 2 - 5 }
\end{tabular}} & & $\begin{array}{l}\text { No. of tagged } \\
\text { birds for which } \\
\text { no data were }\end{array}$ \\
Year & Autumn migration & Spring/return migration & Sedentary individuals & recorded \\
\hline 2009 & 2 (1 female, 1 male $)$ & & $2(1$ female, 1 male $)$ & 6 \\
2010 & 7 (5 females, 2 males $)$ & 0 & $1(1$ male $)$ & 6 \\
2011 & 5 (3 females, 2 males $)$ & $3(2$ females, 1 male $)$ & $7(1$ female, 6 males $)$ & 2 \\
2012 & & $2(2$ females $)$ & & \\
Total & 14 (9 females, 5 males $)$ & 5 & $10(2$ females, 8 males $)$ & 14 \\
\hline
\end{tabular}

(a)

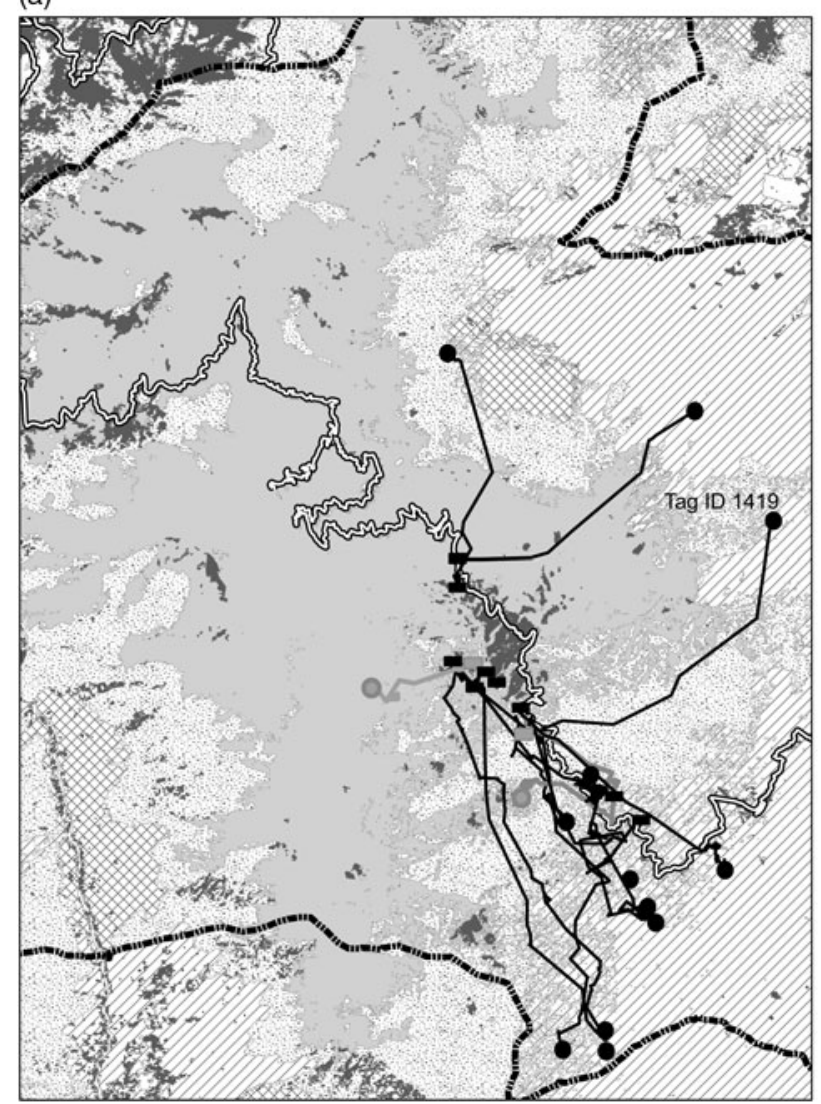

(b)

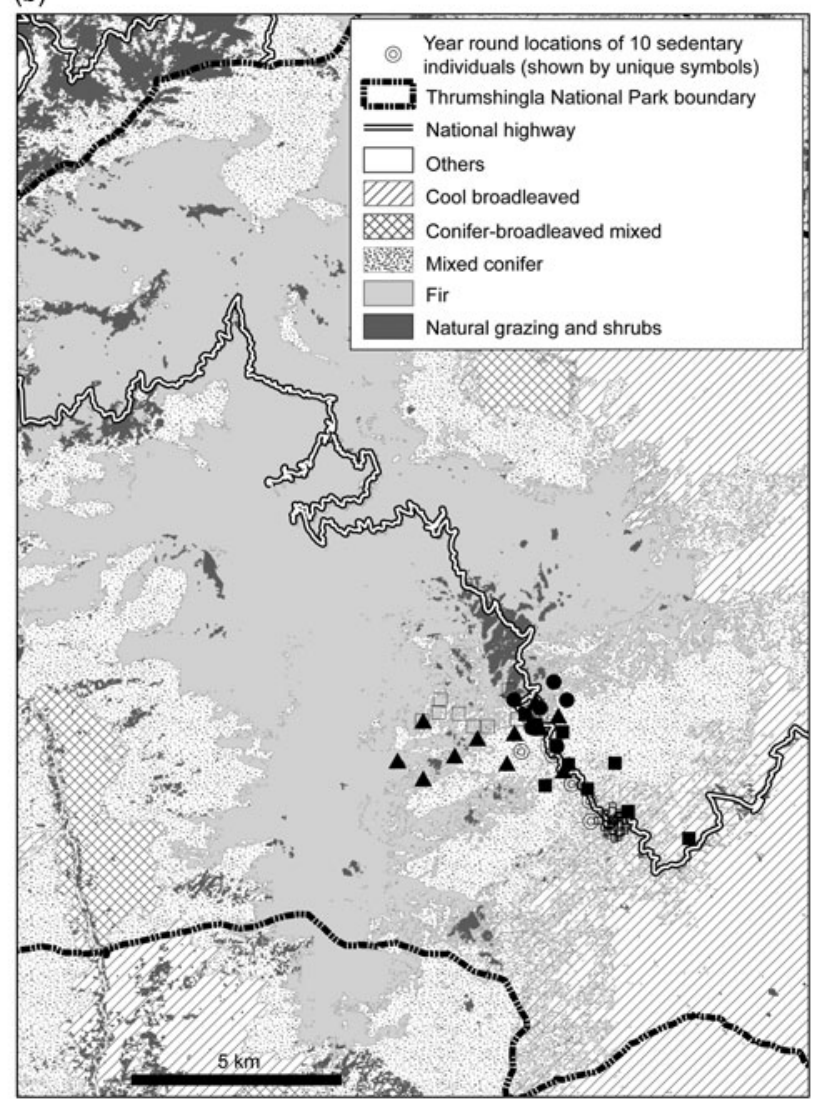

FIG. 2 (a) Autumn migratory routes of 14 satyr tragopans Tragopan satyra, including the individual with tag ID 1419 (Supplementary Fig. S1). Grey lines indicate the routes of two individuals that migrated to higher elevations in winter. The start and end points of the migrations are indicated by filled rectangles and circles, respectively. (b) Year-round locations of resident individuals, each represented by a unique symbol.

Migration patterns, distance and duration Three distinct patterns of migration were recorded: seven individuals (five females and two males) crossed multiple mountains between summer breeding and winter non-breeding grounds; five individuals (three females and two males) descended longitudinally (i.e. parallel to mountain slopes) to winter grounds; and two individuals (one female and one male) climbed to higher elevations during winter. The birds traversed a mean distance of $6.68 \pm 95 \%$ CI $2.11 \mathrm{~km}$ between summer and wintering grounds, in $11.07 \pm 95 \% \mathrm{CI}$ 5 days. Individuals crossing multiple mountains migrated further than individuals descending longitudinally $(\mathrm{n}=12$, $t=3.815, \mathrm{P}=0.003$ ). However, there were no significant differences in the number of migration days between those two categories $(\mathrm{n}=12, t=0.788, \mathrm{P}=0.449)$. Given that only two individuals climbed to higher elevations in 
winter, we excluded them from the analyses of migratory distances and days travelled. Females traversed a mean distance of $6.91 \pm 95 \%$ CI $3.16 \mathrm{~km}$, migrating preferentially in a south-easterly direction, with a mean bearing of $160.62^{\circ}$ ( $\mathrm{n}=9$; Rayleigh test, $\left.\mathrm{P}=0.012\right)$, whereas males migrated in random directions $(\mathrm{n}=5$; Rayleigh test, $\mathrm{P}=0.42$ ), covering a mean distance of $6.87 \pm 95 \%$ CI 3.71 $\mathrm{km}$. All migrants remained within the boundaries of Thrumshingla National Park (Fig. 2a). Of the 14 migrants, seven crossed the highway once and two crossed it at two locations during their migration.

Mode of migration Tragopan migration is not a single-flight event. The birds covered the migratory distance by walking, interspersed with short bouts of running/flight. When the migration spread over multiple days and involved crossing multiple mountains, the birds stopped to rest on mountain slopes (Supplementary Fig. S1). For all migrants throughout the migratory period bouts of running/flight (median $=13.16)$ were significantly less frequent than bouts of walking (median $=182.36$ ). All bouts of running/flight were singular events lasting $<_{2}$ minutes. Resting bouts (median $=520.30$ ) were in turn significantly more frequent than both walking and flight/ running bouts (Kruskal-Wallis ANOVA: $H=36.468$, $\mathrm{P}<0.001$; Tukey test: rest vs flight, $\mathrm{q}=8.54, \mathrm{P}<0.05$; rest vs walk, $\mathrm{q}=4.27, \mathrm{P}<0.05$; walk vs flight, $\mathrm{q}=4.27, \mathrm{P}<0.05$ ).

Habitats used For 20 individuals we obtained complete data for the winter months of December, January and February, and for eight individuals we obtained complete data for May, June and July. Migratory individuals used all forest types (fir, mixed conifer and cool broadleaved; Figs 2a \& 3) in the study area (Fig. 1). Over an 8-month period (September-April) we identified a significant change in the pattern of habitat use (generalized linear model; for cool broadleaved forest: adjusted $\mathrm{R}^{2}=0.7866$, $\mathrm{P}=0.009$; for mixed conifer forests: adjusted $\mathrm{R}^{2}=0.7866$, $\mathrm{P}=0.009$ ), with migrants using cool broadleaved forests more frequently, switching from high-elevation fir and mixed conifer forests during winter (NovemberFebruary). Nevertheless, the tragopans did not completely abandon mixed-conifer forests during winter $\left(\chi^{2}\right.$ test: $\mathrm{df}=2, \mathrm{P}=0.8781$ ), with residents and some migrants still continuing to inhabit these forests. Five of 10 residents remained only within mixed-conifer forests throughout the year, two remained only within cool broadleaved forests, two used both mixed conifer and cool broadleaved forests, and one used a mix of mixed conifer, coniferbroadleaved and cool broadleaved forest (Fig. 2b).

Selection of aspect Residents preferred south-west facing slopes $(\mathrm{n}=12$; Rayleigh test, $\mathrm{P}=0.016)$ at a mean aspect

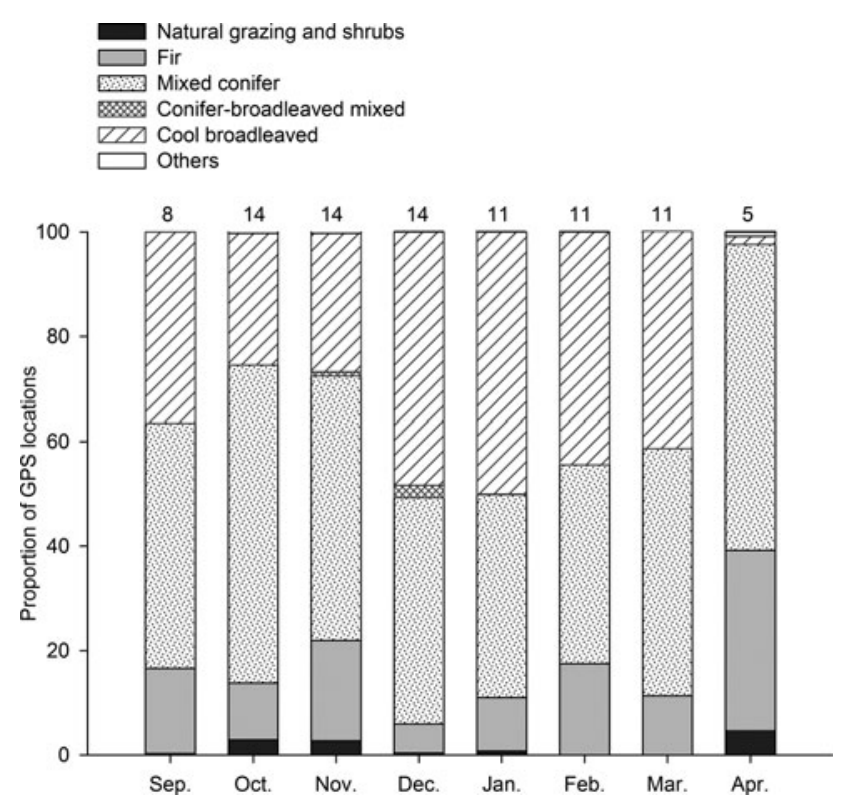

FIG. 3 Habitat use by satyr tragopans in Thrumshingla National Park (Fig. 1) in each month, as indicated by the proportion of GPS fixes recorded in each habitat type. Numbers above the bars indicate total number of individuals for which GPS fixes were obtained in a given month.

(mean vector, $\mu$ ) of $235.47^{\circ}$ during winter (DecemberFebruary). During the same period migrants preferred south-east facing slopes $(\mathrm{n}=12$; Rayleigh test, $\mathrm{P}=0.003)$ at a mean aspect of $122.062^{\circ}$ (Fig. 4). During summer (MayJuly) both migrants and residents preferred to stay on south-west facing slopes $(\mathrm{n}=8 \quad(6$ sedentary and 2 migrants); Rayleigh test, $\mathrm{P}=0.002$; Fig. 4).

\section{Discussion}

In general, altitudinal migrants have been poorly studied, and this is especially the case in the Himalayas. Our study of the satyr tragopan in Bhutan yielded new information that will inform the conservation of this species and possibly other terrestrial, forest-dependent altitudinal migrants, particularly Galliformes. Whereas some of the individuals in our study population simply moved down a mountain for the winter, others chose to cross multiple mountains to reach a suitable winter range. A simplistic conservation plan focused on protecting habitats along elevational bands on a given mountain slope would not protect those individuals travelling between and across mountains. Moreover, tragopans migrate predominantly by walking, interspersed with short bouts of running or flight through the forest. This raises the possibility that certain forms of landuse change could create barriers to the species' migration, and underscores the need to protect contiguous tracts of suitable habitat. 
(a)

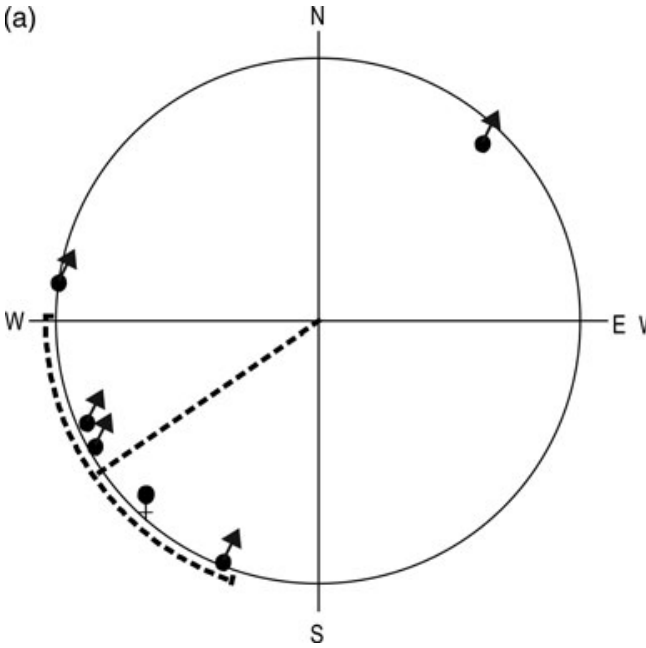

(b)

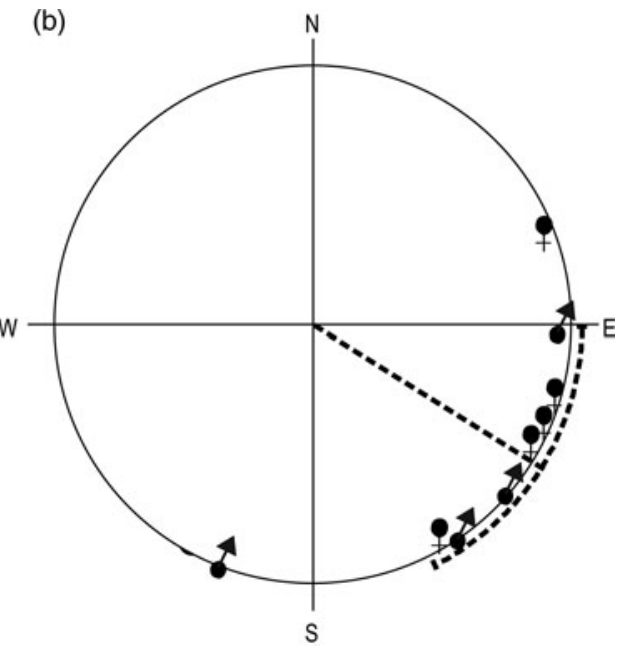

FIG. 4 Preferred aspect of (a) resident satyr tragopans and (b) migrants in Thrumshingla National Park (Fig. 1) during the winter months (December-February). Mean aspect and confidence intervals are indicated by the dashed line and dashed arc, respectively.
The conservation requirements for birds that migrate primarily by walking may be more similar to those of migrating ungulates than to birds that migrate by flying. As is the case with migratory ungulates (Bolger et al., 2008), barriers and land-use changes along migratory routes can be detrimental to birds such as tragopans. Unlike ungulates (Williamson \& Williamson, 1984; Ben-Shahar, 1993; Mwangi, 1998), however, the tragopan's ability to fly even short distances may render it less susceptible to minor barriers such as fences.

Migratory tragopans used all forest types across their annual cycles, using mostly high-elevation fir and mixed conifer forests in summer and cool broadleaved forests in winter. Residents and a few migrants continued to use mixed conifer forests during winter, thus it is important to protect contiguous tracts of all habitat types across all seasons. Similar observations were made by Powell \& Bjork $(1995,2004)$ for altitudinally migrating birds in Costa Rica.

Changes in habitat use from summer to winter were not a simple transition to lower-elevation forests (and vice-versa during spring). Our results reveal a complex pattern whereby individuals also migrated within a single habitat type (i.e. from higher-elevation mixed conifer forest to lowerelevation mixed conifer forest). Two individuals migrated to lower elevations within a forest transition complex consisting of patches of mixed conifer and cool broadleaved forests, whereas one female and one male migrated to higher-elevation fir forests from mixed-conifer forests during winter. In addition to supporting the need to protect forest habitats with adequate representation of all habitat types, our data also highlight the importance of individual differences and choice (Bolnick et al., 2003) in shaping migratory patterns.

In addition to protecting all habitat types, we propose an additional requirement for the effective conservation of altitudinally migrating species within montane environments: conservation of aspect diversity. Migratory tragopans differ from their sedentary counterparts in their choice of aspect during winter, with migrants switching from south-east to south-west facing slopes while residents continue to reside on south-east facing slopes. We propose that protected areas, in addition to having representative habitat types, should also have adequate representation of all aspects within a landscape. Protecting a diversity of aspects could also benefit the conservation of a variety of other altitudinal migrants (Poole et al., 2009; Zeng et al., 2010).

Over an annual cycle we observed that north-west facing slopes were not preferred by any of the individuals, resident or migratory, that we tracked. Within Thrumshingla National Park almost 11\% (c. $104 \mathrm{~km}^{2}$ ) of the total area has a north-west aspect, and studies targeted at estimating the tragopan population size in the Park should perhaps consider excluding north-west facing slopes as suitable habitats. However, our sample size is small and we suggest that further study of aspect preference should be conducted to verify our assertion. Nonetheless, across protected areas in montane regions, if altitudinal migrants exhibit such preferences, population estimates may need to be revised.

Studies have shown continuing loss of forest cover across many regions (Hansen et al., 2013). However, we remain optimistic that migrants can persist in countries such as Bhutan where protected areas have retained their forests (Thrumshingla National Park has an estimated 95\% forest cover) and large-scale commercial harvesting of forest within protected areas is not permitted. All the migrants we tracked remained within the boundaries of the Park, and their migratory tracks covered c. one third of the Park's area. It may therefore be necessary to protect large areas for the sake of relatively few migrants, and in this regard a detailed assessment of park sizes and migrant distribution across montane regions would be of value.

We hypothesize that the movement of migrants to areas outside the Park boundaries may be restricted by human settlements surrounding the Park. Additional studies are 
necessary to determine the types and intensities of land uses that tragopans can tolerate. Several migrants crossed the national highway at multiple locations, suggesting that the highway is not currently a barrier to tragopan migration. This could be because highways in Bhutan are narrow (mean width $<3 \mathrm{~m}$ ). Increases in traffic intensity and highway width should therefore be monitored to track potential risks for migrants.

Our findings are relevant to discussions regarding the role of habitat corridors in protecting biodiversity. Given ongoing deforestation (Hansen et al., 2013) and other landuse changes that impede migration, the concept of connecting protected areas with habitat corridors has gained prominence. However, much remains to be learned regarding the effectiveness of such corridors (Hobbs, 1992; Beier \& Noss, 1998). Our finding that female tragopans tend to migrate in a south-easterly direction whereas males have no particular orientation suggests that corridors are likely to be no more than partially successful in protecting tragopan migrations. For male tragopans in particular, corridors may prove to be a poor substitute for large, continuous blocks of forest.

Given that most montane bird species of Bhutan and the Himalayas are altitudinal migrants, and given the complex patterns of migration and habitat use exhibited by a single species, the satyr tragopan, it seems clear that more research on altitudinal migrants is needed to understand fully what will be required to ensure their future in an era of widespread land-use and climate change.

\section{Acknowledgements}

We are grateful to the International Max Planck Research School for Organismal Biology and the Max Planck Institute for Ornithology, Radolfzell, for funding this work.

\section{References}

Beier, P. \& Noss, R.F. (1998) Do habitat corridors provide connectivity? Conservation Biology, 12, 1241-1252.

Ben-Shahar, R. (1993) Does fencing reduce the carrying capacity for populations of large herbivores? Journal of Tropical Ecology, 9, 249-253.

Bird Life International (2012a) Tragopan satyra. In The IUCN Red List of Threatened Species v. 2015.2. Http://www.iucnredlist.org [accessed 11 August 2015].

BirdLife International (2012b) Species factsheet: Satyr tragopan Tragopan satyra. Http://www.birdlife.org/datazone/ speciesfactsheet.php?id=238 [accessed 2 November 2012].

Birdlife International (2015) Endemic Bird Area factsheet: Eastern Himalayas. Http://www.birdlife.org/datazone/ebafactsheet. php?id=129 [accessed 19 May 2015].

Blyth, S., Groombridge, B., Lysenko, I., Miles, L. \& Newton, A. (2002) Mountain Watch: Environmental Change \& Sustainable Development in Mountains. UNEP-WCMC, Cambridge, UK.
Bolger, D.T., Newmark, W.D., Morrison, T.A. \& Doak, D.F. (2008) The need for integrative approaches to understand and conserve migratory ungulates. Ecology Letters, 11, 63-77.

Bolnick, D.I., Svanbäck, R., Fordyce, J.A., Yang, L.H., Davis, J. M., Hulsey, C.D. \& Forister, M.L. (2003) The ecology of individuals: incidence and implications of individual specialization. The American Naturalist, 161, 1-28.

Bотн, C., Bouwhuis, S., Lessells, C.M. \& Visser, M.E. (2006) Climate change and population declines in a long-distance migratory bird. Nature, 441, 81-83.

Bowlin, M.S., Bisson, I.-A., Shamoun-Baranes, J., Reichard, J. D., SAPIR, N., MARRA, P.P. et al. (2010) Grand challenges in migration biology. Integrative \& Comparative Biology, 50, 261-279.

Brooks, T.M., Bakarr, M.I., Boucher, T., Da Fonseca, G.A.B., Hilton-Taylor, C., Hoekstra, J.M. et al. (2004) Coverage provided by the global protected-area system: is it enough? BioScience, 54, 1081-1091.

Brown, D.D., Kays, R., Wikelski, M., Wilson, R. \& Klimley, A.P. (2013) Observing the unwatchable through acceleration logging of animal behavior. Animal Biotelemetry, 1, 20.

Burgess, N.D. \& Mlingwa, C.O.F. (2000) Evidence for altitudinal migration of forest birds between montane Eastern Arc and lowland forests in East Africa. Ostrich, 71, 184-190.

Cade, B.S. \& Hoffman, R.W. (1993) Differential migration of blue grouse in Colorado. The Auk, 110, 70-77.

Cantú-Salazar, L., Orme, C.D.L., Rasmussen, P.C., Blackburn, T.M. \& GAston, K.J. (2013) The performance of the global protected area system in capturing vertebrate geographic ranges. Biodiversity and Conservation, 22, 1033-1047.

Chaves-Campos, J., Arévalo, J.E. \& Araya, M. (2003) Altitudinal movements and conservation of bare-necked umbrellabird Cephalopterus glabricollis of the Tilarán Mountains, Costa Rica. Bird Conservation International, 13, 45-58.

Chettri, N., Shakya, B., Thapa, R. \& Sharma, E. (2008) Status of a protected area system in the Hindu Kush-Himalayas: an analysis of PA coverage. International Journal of Biodiversity Science and Management, 4, 164-178.

CITES (2015) The CITES Appendices. Http://www.cites.org/eng/app/ index.shtml [accessed 11 August 2015].

ERvin, J. (2003) Rapid assessment of protected area management effectiveness in four countries. BioScience, 53, 833-841.

Faaborg, J., Holmes, R.T., Anders, A.D., Bildstein, K.L., Dugger, K.M., Gauthreaux, JR, S.A. et al. (2010) Recent advances in understanding migration systems of New World land birds. Ecological Monographs, 80, 3-48.

Grimmet, R., Inskipp, C. \& Inskipp, T. (200o) Birds of Nepal. Princeton University Press, Princeton, USA

Hansen, M.C., Potapov, P.V., Moore, R., Hancher, M., Turubanova, S.A., Tyukavina, A. et al. (2013) High-resolution global maps of 21st-century forest cover change. Science, 342, 850853 .

Harris, G., Thirgood, S., Hopcraft, J.G.C., Cromsigt, J.P.G.M. \& BERGER, J. (2009) Global decline in aggregated migrations of large terrestrial mammals. Endangered Species Research, 7, 55-76.

Haw Kins, P. (2004). Bio-logging and animal welfare: practical refinements. Memoirs of National Institute of Polar Research, 58, 58-68.

Hess, S.C., Leopold, C.R., Misajon, K., Hu, D. \& Jeffrey, J.J. (2012) Restoration of movement patterns of the Hawaiian goose. The Wilson Journal of Ornithology, 124, 478-486.

Hоввs, R.J. (1992) The role of corridors in conservation: solution or bandwagon? Trends in Ecology \& Evolution, 7, 389-392.

Holland, R.A., Wikelski, M. \& Wilcove, D.S. (2006) How and why do insects migrate? Science, 313, 794-796. 
Inouye, D.W., Barr, B., Armitage, K.B. \& Inouye, B.D. (2000) Climate change is affecting altitudinal migrants and hibernating species. Proceedings of the National Academy of Sciences of the United States of America, 97, 1630-1633.

Inskipp, C., Inskipp, T. \& Grimmet, R. (1999) Birds of Bhutan. Christopher Helm Publishers Ltd, London, UK.

Kapos, V., Rhind, J., Edwards, M., Price, M.F., Ravilious, C., Kremsa, V. et al. (2000) Developing a map of the world's mountain forests. In Forests in Sustainable Mountain Development: A State of Knowledge Report for 2000 (eds M.F. Price \& N. Butt), pp. 4-19. CABI Publishing, Wallingford, UK.

LAYMON, S.A. (1989) Altitudinal migration movements of spotted owls in the Sierra Nevada, California. The Condor, 91, 837-841.

Martin, T.G., Chadès, I., Arcese, P., Marra, P.P., Possingham, H. P. \& NORRIS, D.R. (2007) Optimal conservation of migratory species. PLoS ONE, 2(8), e751.

Ministry of Agriculture and Forests (2011) Landcover Atlas of Bhutan. Ministry of Agriculture and Forests, Thimphu, Bhutan.

Møller, A.P., Rubolini, D. \& Lehikoinen, E. (2008) Populations of migratory bird species that did not show a phenological response to climate change are declining. Proceedings of the National Academy of Sciences of the United States of America, 105, 16195-16200.

Moore, F.R., Gauthreaux, Jr, S.A., Kerlinger, P. \& Simons, T.R. (1995) Habitat requirements during migration: important link in conservation. In Ecology and Management of Neotropical Migratory Birds: A Synthesis and Review of Critical Issues (eds T.E. Martin \& D. M. Finch), pp. 121-144. Oxford University Press, New York, USA.

Movebank (2015) Https://www.movebank.org/ [accessed 11 August 2015].

Mwangi, E.M. (1998) Large herbivore dynamics in the face of insularization: the case of Lake Nakuru National Park, Kenya. African Journal of Ecology, 36, 276-279.

Nogués-Bravo, D., Araújo, M.B., Errea, M.P. \& MARTíneZ-RicA, J.P. (2007) Exposure of global mountain systems to climate warming during the 21st century. Global Environmental Change, 17, 420-428.

Norbu, N., Wikelski, M.C., Wilcove, D.S., Partecke, J., Ugyen Tenzin, U. et al. (2013) Partial altitudinal migration of a Himalayan forest pheasant. PLoS ONE, 8(4), e60979.

Pandit, M.K., Sodhi, N.S., Koh, L.P., Bhaskar, A. \& Brook, B.W (2007) Unreported yet massive deforestation driving loss of endemic biodiversity in Indian Himalaya. Biodiversity and Conservation, 16, 153-163.

Poole, K.G., Stuart-Smith, K. \& Teske, I.E. (2009) Wintering strategies by mountain goats in interior mountains. Canadian Journal of Zoology, 87, 273-283.

Powell, G.V.N. \& BJORK, R.D. (1994) Implications of altitudinal migration for conservation strategies to protect tropical biodiversity: a case study of the resplendent quetzal Pharomachrus mocinno at Monteverde, Costa Rica. Bird Conservation International, 4, 161-174.

Powell, G.V.N. \& BJORK, R. (1995) Implications of intratropical migration on reserve design: case study using Pharomachrus mocinno. Conservation Biology, 9, 354-362.
Powell, G.V.N. \& BJork, R.D. (2004) Habitat linkages and the conservation of tropical biodiversity as indicated by seasonal migrations of three-wattled bellbirds. Conservation Biology, 18, 500509.

R Development Core Team (2014) R: A Language and Environment for Statistical Computing. R Foundation for Statistical Computing, Vienna, Austria.

Roever, C.L., van Aarde, R.J. \& Leggett, K. (2013) Functional connectivity within conservation networks: delineating corridors for African elephants. Biological Conservation, $157,128-135$.

Shrestha, U.B., Gautam, S. \& BAwa, K.S. (2012) Widespread climate change in the Himalayas and associated changes in local ecosystems. PLoS ONE, 7(5), e36741.

Stiles, F.G. (1988) Altitudinal movements of birds on the Caribbean slope of Costa Rica: implications for conservation. In Tropical Rainforests: Diversity and Conservation (eds F. Almeda \& C.M. Pringle), pp. 243-258. California Academy of Sciences, San Francisco, USA.

Terborgh, J., van Schaik, C., Davenport, L. \& Rao, M. (2002) Making Parks Work: Strategies for Preserving Tropical Nature. Island Press, Washington, DC, USA.

Thirgood, S., Mosser, A., Tham, S., Hopcraft, G., Mwangomo, E., Mlengeya, T. et al. (2004) Can parks protect migratory ungulates? The case of the Serengeti wildebeest. Animal Conservation, 7, 113-120.

W Ilcove, D.S. (2008) No Way Home: The Decline of the World's Great Animal Migrations. Island Press, Washington, DC, USA.

Wilcove, D.S. \& Wikelski, M.C. (2008) Going, going, gone: is animal migration disappearing. PLoS Biology, 6(7), e188.

Williamson, D. \& Williamson, J. (1984) Botswana's fences and the depletion of Kalahari wildlife. Oryx, 18, 218-222.

Wilson, R.P., Shepard, E.L.C. \& Liebsch, N. (2007) Prying into the intimate details of animal lives: use of a daily diary on animals. Endangered Species Research, 3, 1-15.

Zeller, K.A., McGarigal, K. \& Whiteley, A.R. (2012) Estimating landscape resistance to movement: a review. Landscape Ecology, 27, 777-797.

ZENG, Z., BECK, P. \& WANG, T. (2010) Effects of plant phenology and solar radiation on seasonal movement of golden takin in the Qinling Mountains, China. Journal of Mammalogy, 91, 92-100.

\section{Biographical sketches}

NAWANg Norbu uses science and policy to inform conservation and management of forests. UGYEN is interested in biodiversity assessment, and management of threatened wildlife species. MARTIN WIKELSKI studies global wildlife migration systems and their impacts on the environment and society. D A V ID W ILCOVE combines research in ecology and the social sciences for the protection of global biodiversity and migratory phenomena. 